\title{
Information Policy Advocacy and Lobbying
}

\author{
Dr. Chipo Mutongi ${ }^{1}$, Dr. S. B. M. Marume ${ }^{2}$ \\ ${ }^{I}$ Dip-Edu, HND-LIS, Dip. Personnel Mgnt, BA, MBA, MSc, PhD \\ ${ }^{2} B A$, Hons BA, MA, MAdmin, MSoc Sc, PhD \\ Zimbabwe Open University, City of Harare
}

\begin{abstract}
If some ideas, decisions and policies are not advocated and lobbed for, they would remain unknown to implementers and to the general public. It is imperative to advocate and lobby for different information policies in order for those in power to see the value and reasons for the formulation and implementation of the information policies. Probably it is lack of awareness that is not bringing those policy changes. This article explores information policy advocacy and lobbying as well as distinguishing information policy advocacy from lobbying. Some reasons for information policy advocacy failure are given and some ways of making information policy advocacy a success are established.
\end{abstract}

Keywords: Information policy, advocacy, lobbying, policy analysis, policy makers, legislation, information management, change.

\section{INTRODUCTION}

The information and knowledge economy calls for skills in information policy advocacy and lobbying. Before direct action comes planning, and before planning comes an understanding of what needs to be put in the plan (Community Tool Box, 2016). Information policy advocacy and lobbying are necessary to create awareness and influence regarding information issues on policy agenda. This article gives an insight into information policy advocacy and lobbying. Policy Analysis versus Policy advocacy is discussed. A distinction is made of information policy advocacy and lobbying. The importances of policy advocacy are highlighted.

\section{OBJECTIVES}

The objectives of this article are to:

- define information policy advocacy

- compare and contrast policy analysis and advocacy

- distinguish advocacy from lobbying

- identify the importance of information policy advocacy

- indicate the reasons for information advocacy failure

- give recommendations for the success of information policy advocacy.

\section{WHAT IS ADVOCACY?}

Mlanga (2012) asserts that advocacy is to speak on behalf of; to positively argue on behalf of another. It means communication, as an individual or group: with decision makers, and others in support of; or opposition to specific issues. It encompasses pleading for or against causes as well as supporting or recommending positions (LWV, 2016).

Advocacy:

- $\quad$ is active promotion of a cause or principle

- involves actions that lead to a selected goal

- $\quad$ is one of many possible strategies, or ways to approach a problem

- can be used as part of a community initiative, nested in with other components

- $\quad$ is not direct service

- does not necessarily involve confrontation or conflict. (Source: Community Tool Box, 2006)

Advocacy is an active support of an idea or cause etc.; especially the act of pleading or arguing for something such as a cause, idea or policy. Advocacy comes in many forms. It can be communicating with your elected officials, government regulators, insurers, the media and the general public. It is a deliberate process of influencing those who make policy decisions. Policy advocacy is the process of negotiating and mediating a dialogue through which influential networks, opinion leaders, and ultimately, decision makers take ownership of your ideas, evidence, and proposals, and subsequently act upon them (ICPA, 2014). 
We should not confuse a service with advocacy. The following are examples taken from (Community Tool Box, 2006) which indicate what advocacy is and what advocacy is not:

- You join a group that helps build houses for the poor - that is wonderful, but it is not advocacy (it is a service)

- You organise and agitate to get a proportion of apartments in a new development designated as low to moderate income housing - that is advocacy

- You spend your Saturdays helping sort out goods at the recycling center - that is not advocacy (it is a service)

- You hear that land used for the recycling centre is going to be closed down and you band together with many others to get the city to preserve this site, or find you a new one. Some of you even think about blocking the bulldozers, if necessary - that is advocacy

\subsection{Information policy advocacy}

Information policy advocacy therefore is the process of negotiating, mediating and influencing those who make decisions on new information policy introduction or changes on some aspects of the information policy. If advocates do their job well, decision makers will take the ideas that have been put forward and introduce the new information policy or make changes to the current policy approach in line with that thinking advocated for regarding the information policy. This can be done at organisational, national and global level.

\section{POLICY ANALYSIS VERSUS POLICY ADVOCACY}

Dye (1987:70) asserts that it is important to distinguish policy analysis from policy advocacy. Explaining the causes and consequences of various policies is not equivalent to prescribing what policies government ought to pursue. Policy advocacy requires the skills of rhetoric, persuasion, organisation and activism. Policy analysis encourages scholars and students to attack critical policy issues with the tolls of systematic inquiry. The policy analysis is a prerequisite to prescription, advocacy and activism.

\section{IMPORTANCE OF AN INFORMATION POLICY ADVOCACY}

The following are some of the importance of policy advocacy:

- increases awareness of the information policy adoption and changes

- $\quad$ encouraging the adoption of the information policy

- improve access to information regarding the information policy

- results in new information policies

- $\quad$ advocacy frequently involves building constituencies which are groups of people and organisations who support information policy issues

- $\quad$ it is a strategy to influence policy makers regarding information policy and in the distribution of resources and make other decisions that affect information management

- advocacy can change community attitudes and misconceptions regarding information management and policy

- $\quad$ it can assist people to gain access to resources and funding

- $\quad$ advocacy can help make service providers and organisations accountable ensuring there is transparency in their actions and decisions

- $\quad$ ensures that you have a voice and that it will be heard

- $\quad$ it can also promote positive change.

\section{LOBBYING}

Lobbying is called for to try to influence the thinking of legislators or other public officials for or against a specific cause for example lobbying for a national information policy. It is "an organised attempt by a group of people to influence politicians on particular issue" (Oxford Advance Learner's Dictionary, 2010) Haynes and Mickelson (1997:97) argue that at the beginning of any lobbying effort, the lobbyist must keep in mind that many checks and balances are built into the legislative process and that legislators can be influenced in numerous ways. The process is complex, with formal as well as informal variables, hundreds of concerns and points of view are presented before any legislative body. Thus a lobbyist must be patient and persistent. In addition to patience and persistence, another important attribute of a lobbyist is the ability to acknowledge the merits of competing proposals. A lobbyist's role is to mobilise the strongest and most persuasive arguments for a particular position in this case, the information policy. When a lobbyist becomes unable or unwilling to acknowledge the merits of an alternative proposal, he/she is seen as a propagandist and any credibility and eventual utility may be reduced (Petti and Ronald, 1981). Haynes and Miclelson (1997:97) add that the lobbyist should bear in mind the following guidelines: 
- Know your issues thoroughly. Anticipate the opposition's claims and formulate persuasive counter arguments. Be prepared to provide technical information that will be useful to the legislators.

- Identify a strong group of committed and effective workers who will lead a coalition of interested groups and individuals who can be called on to write letters, lobby or publicise the issue.

- Locate the lawmaker who is sympathetic to your issue and is likely to be effective in advancing the cause and continue to work with him/her for the duration of the process.

- Be familiar with the formal legislative structure and the procedural steps for the issues to become a policy.

- Spend as much time as possible at the capitol (a building occupied by a state legislature), both to answer legislators' questions and to be in a position to intervene effectively at the critical moment, by offering advice or information before decisions have been made.

\subsection{Face to face lobbying}

Face to face lobbying is conducting meetings and discussions with relevant people. Face to Face lobbying approach does not just aim to arrange meetings. It aims for meetings that will be successful. They are a lot more work, but they have a lot more value. Information workers who are naïve about legislators and the political process believe that legislators are not approachable. It becomes easier for them to write letters, sign petitions or join coalitions than to interact directly with legislators. Nevertheless, legislators need direct interaction and may even seek it from various individuals and groups. They might realise that they are very much isolated and protected from the reality and therefore must rely on input from credible sources. The legislators will grant an appointment on request.

\subsection{Key approaches to lobbying}

The following are some of the key approaches to lobbying:

- Involve leaders: leaders refer to those who are extremely influential in facilitating policy formulation and implementation.

- Build partnerships: Partnerships are formed by groups of individuals that join together aiming to accomplish a purpose.

- Mobilise the community groups: the purpose of mobilising community groups is to draw attention of the leaders towards the information policy issues and to encourage them to take action. It helps planners to collect data, testimonials and information regarding information policy. It also helps in the dissemination of information so as to get support of the information policy.

- Capacity building: Capacity building is the development of knowledge, competence, skills and attitudes in individuals and groups of people relevant in the design, development and maintenance of processes and activities that are locally meaningful. Capacity building approach is used for leadership development, expanding network and advocates, maintaining high level of knowledge competence and skills and keeping up with new trends and challenges.

- Work with mass media: The reasons for dealing with media include enhancing visibility of your programme and/or organisation name recognition and inform the policy makers and the public about your activities regarding the information policy. Bonser et al (1996:46) stipulate that the media has a significant effect on the issues when the media elevates issues to the point where they attract the attention of those able to make decisions about them. The media also stimulate discussion on issues of information policy, generates public support for your activities and organisation as well as increase fundraising, sponsorship and membership or supporters to the information policy. It makes the need for information policy noticed and prioritised.

\subsection{Kinds of Lobbying}

Grassroots and direct lobbying are different kinds of lobbying.

6.3.1 Grassroots lobbying: Any attempt to influence legislation by affecting the opinion of the general public is regarded as grassroots lobbying. In this case the organisation encourages the public to lobby. The organization refers to a specific piece of legislation and provides information to the public on how to contact decision makers. Under certain circumstances mass media acts as an example of grassroots lobbying. The media can be directed to a general public so as to express a view on specific legislation and might include statement that directs readers to contact their legislators.

6.3.2 Direct lobbying: Any attempt to influence legislation through communication with any member or employee of a legislative body, or with any other government official who may participate in the formulation of legislation is regarded as direct lobbying. A specific activity constitutes direct lobbying if: The principal purpose is to influence legislation, there is reference to a specific piece of legislation (even if the legislation is 
not currently under consideration) and a point of view is expressed to the legislative body. Direct lobbying calls for a communication which is directed to a legislators(s), its staff or other government employee(s) who may participate in the formulation of legislation(LWV,2016). It can also refer to expressing a view on specific legislation.

\section{ADVOCACY VERSUS LOBBYING}

Figure 1 illustrates advocacy and lobbying.

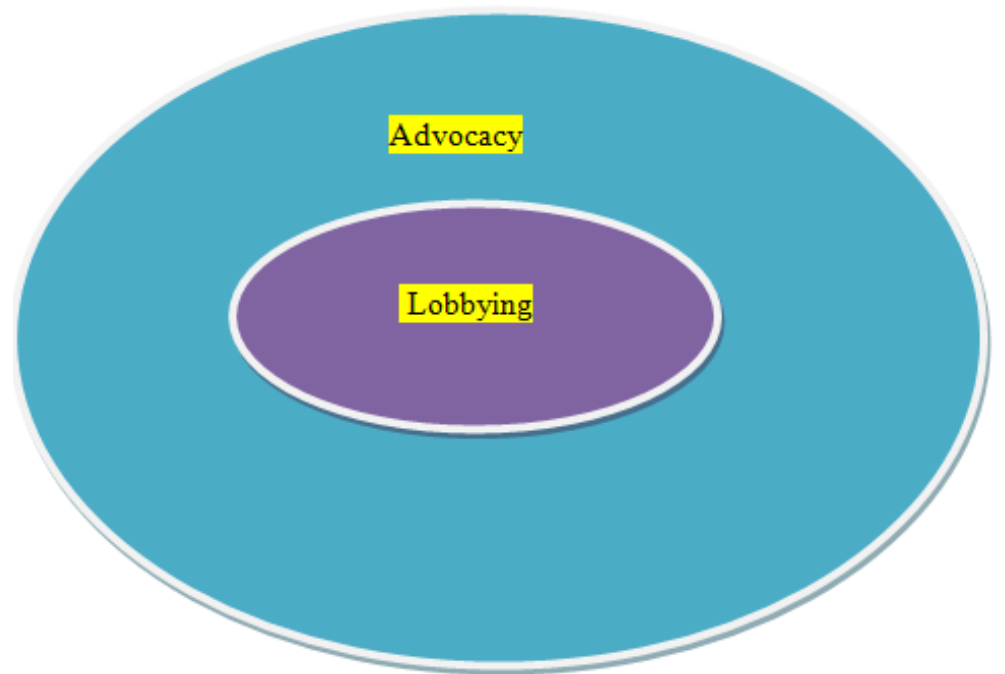

Figure 1: Advocacy and lobbying

The figure 1 illustrates that all lobbying is advocacy but not all advocacy is lobbying. This shows that lobbying is part of advocacy strategy but not all advocacy incorporate lobbying. It therefore points that lobbying is a subset of advocacy. Advocacy is the act of arguing in favor of something or against something. It involves an individual or group of people airing their concerns thus 'raising their voice' in order to be heard. Thus, they will be peaking in one voice. It is any attempt to influence specific legislation (Washing Nonprofits and The Board Advocacy Project, 2014). Lobbying involves attempts to influence specific legislation at the organisational, local, national and global level while advocacy is focused on educating about a specific issue. Lobbying makes up a small portion of the total amount of advocacy efforts. Advocacy are actions that aim to create awareness and change attitudes in this case changing attitudes towards information management issues and policy whilst lobbying is influencing specific decision making on information policy formulation and implementation. Lobbying focuses on influencing the thinking of people in power whilst advocacy is broader as it focuses on active support of an idea, cause or policy in this case issues regarding information policy. Advocacy speaks on behalf of or against an issue whilst lobbying influence the thinking of policy makers.

\section{REASONS FOR INFORMATION POLICY ADVOCACY FAILURE}

Kyle (2012) indicates that advocacy can fail due to lack of vision and statement as well as lack of goals, objectives and plan. Kotter (1996:7) opines that "without an appropriate vision, a transformation effort can easily dissolve into a list of confusion, incompatible and time consuming projects that go in the wrong direction or nowhere at all". It is general said that failure to plan is planning to fail. If there is no realistic budget advocacy is bound to fail. Lack of involvement and participation result in advocacy failure. There is need for buying in from all stakeholders. Wrong timing can negatively affect advocacy. If there are no perceived benefits and lack of training advocacy will not be successful. Inability to create short term wins affect advocacy. Lack of knowledge and professional assistance result in advocacy failure. Expectations that are unrealistic also lead to advocacy failure.

\section{RECOMMENDATIONS}

The following recommendations are made for effective and efficient advocacy:

- There is need to analyse and understand the environment which is both the internal and external environment so that proper actions and procedure are taken. Burns (2004), shows the same sentiments when he avers that there is "need to develop the ability to collect and utilise information about the external and internal environments. This will result in the understanding of the environment that the information policy advocates will be working in and how are they will interact with the public and policy makers. 
- Always highlight the positive values and vision relating to the information policy

- Creation of a shared vision and mission with specific and attainable objectives and effective plan and an implementation plan. Vision, for all power and potential, is not worth a great deal as long as it remains the private preserve of a single individual (Harrison, 2002)

- $\quad$ Resource mobilisation

- Create sense of urgency. Kotter (1996) emphasis on the establishment of a sense of urgency and creation of short term wins.

- There is need to identify opponents and resistance to the information policy and find ways on how to deal with those opponents and resistance to the information policy advocacy which include encouraging involvement of potential opponents as well as allies

- $\quad$ Effective communication, involvement and participation and honesty are called for.

- Librarians, Records Managers and Archivists as well as other information professionals need to be play a major role as facilitators and change agents in the information policy formulation therefore they have to be at the forefront of information advocacy and lobbying.

\section{CONCLUSION}

It has been established that advocacy is broader than lobbying and lobbying is just an element of advocacy. Advocacy helps in creating awareness, encouragement, result in access to information and build constituency that support the information policy. It results in the new information policy or adjustment of the existing information policy. There are key issues to be considered in lobbying which include anticipating resistance and how to manage it, spending much time on the capitol and locate sympathetic information policy law makers. For effective advocacy, shared vision, mission, objective and plan should be made available. This brings out effective planning. Involvement and participation is called for and creation of short term wins as well as sense of urgency.

\section{REFERENCES}

[1] Bonser, C.F (1996) Policy Choices and Public Action. New Jersey: Prentice Hall.

[2] Burns (2004) Managing change: A strategic Approach to Organisational Dynamics. Harlow: Prentice Hall.

[3] Community Tool Box (2016) Overview: Getting an Advocacy Campaign Off the Ground. Retrieved (21/06/2016) from http://ctb.ku.edu/en/table-of-contents/advocacy/advocacy-principles/overview/main

[4] Dye, R (1987) Understanding Public Policy. Englewood Cliffs: Prentice-Hall, Inc.

[5] Harrison (2002) The Spirit of Leadership: Liberating the Leaders in each of Us. New Delhi: Viva Books Private Limited,

[6] Haynes, K.S and Miclelson, J.S (1997) Affecting Change: Social Workers in the Political Arena. New York: Longman.

[7] Kotter (1996) Leading Change. Boston; Harvard Business School Press.

[8] Kyle, C (2012) Reasons Why Advocacy Programs Fail. Retrieved (14/08/12) from Rhttp://thekylegroup.com/pdf/TKG\%20Why\%20Advocacy\%20Programs\%20Fail!\%206-1-06.pdf

[9] LWV (2016) League of Women Voters: Making Democracy Work. Retrieved (20/06/2016) from http://lwv.org/content/defining-advocacy-vs-lobbying.

[10] Mlanga (2012) Advocacy and Lobbying For People Centered Libraries. Retrieved (13/08/12) from http://www.goethe.de/ins/za/za/pro/lag/kenys-mlanga.pdf.

[11] Oxford Advance Learner's Dictionary (2010) Oxford Advance Learner's Dictionary: International Student's Edition. Oxford: Oxford University Press.

[12] Patti, R and Ronald, D (1981) Legislative Advocacy: Seven Effective Tactics: Social Work. 26 (July), vol.2.

[13] Washing Nonprofits and The Board Advocacy Project (2014). Retrieved (20/06/2016)http://cltnetwork.org/wpcontent/uploads/2014/01/Advocacy-vs-Lobbying-1-28-14-final.pdf

\section{Profiles of contributors and photographs}

Dr. Chipo Mutongi: a part lecturer and a $\mathrm{PhD} / \mathrm{DPhil}$ research thesis supervisor/ understudyat the Zimbabwe

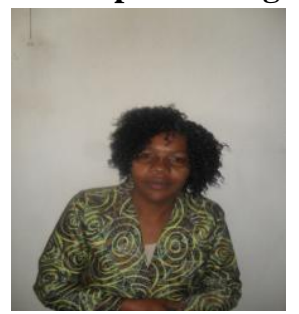
Open University (ZOU), with more than nine years lecturing experience; Research Supervisor for all levels of education; member of the International Board of Reviewers for the International Journal of Doctoral Studies (IJDS); Journal Reviewer-Journal of Information and Knowledge Management (JIKM); published over fifteen articles in International Journals; DCIZ board member-Marketing and Communication, published more than ten modules with Zimbabwe Open University (ZOU); is in the process of coauthoring a book entitled: PUBLIC ADMINISTRATION: theory and practice of methods, procedures and systems; A Talent Management Officer in the City of Harare. Worked as a Librarian at the City of Harare with more than eleven years experience in library, information and knowledge management; attained the highest and most prestigious degree of Doctor of Philosophy in Information and Knowledge Management (ZOU); Master of Science in Library and Information Science 
(NUST); the more professional degree of Master of Business Administration (ZOU); Media Studies Degree (ZOU); Higher National Diploma in Library and Information Science (Harare Polytechnic); Diploma in Library and Information Science (Bulawayo Polytechnic); Diploma in Education (UZ); Diploma in Personnel Management (IPMZ); Diploma in Salaries Administration (Stallone Consultancy); Certificate in Desk Top Publishing (CCOSA); Certificate in Web Designing (People's College); Certificate in Computer Repairs (People's College).

Samson Brown Muchineripi Marume: a former senior civil servant for over 37 years serving in various


capacities of seniority and 10 years as deputy permanent secretary; thirteen years as a large commercial farmer; well-travelled domestically within Zimbabwe; regionally [SADC countries: Angola, Botswana, Lesotho, Malawi, Mozambique, Mauritius, Swaziland, South Africa, Namibia, Tanzania, Zambia and DRC]; and Africa [Kenya, Ethiopia, Sudan, Egypt, Nigeria, Ghana, Libya, and Uganda]; and internationally [Washington, New York and California in USA; Dublin and Cork in Irish Republic; England in United Kingdom; Netherlands, Frankfurt in Germany; Lisbon in Portugal; Spain (Nice), Paris in France, Geneva in Switzerland, Belgrade in former Yugoslavia-; Rome and Turin in Italy; Nicosia - Cyprus; Athens Greece; Beijing and Great Walls of China; Singapore; Hong Kong; Tokyo, Kyoto, Yokohama, and Osaka, in Japan]; fifteen years as management consultant and part - time lecturer for BA/BSc and MA/MBA degree levels with Christ College- affiliate of Great Zimbabwe University and National University of Science and Technology; six years as PhD/DPhil research thesis supervisor, internal and external examiner with Christ University, Bangalore, India [2011 - 2016]; and Zimbabwe Open University; external examiner of management and administrative sciences at Great Zimbabwe University (2016 - 2019); currently senior lecturer and acting chairperson of Department of Public Administration in Faculty of Commerce and Law of Zimbabwe Open University; a negotiator; a prolific writer who has published five books, prepared thirty modules in public administration and political science for undergraduate and postgraduate students, and published over seventy referred journal articles in international journals [IOSR, IJSR, ISCA - IRJSS, IJESR, MJESR, IJESI, IJBMI, IJHSS and Quest Journals] on constitutional and administrative law, public administration, political science, philosophy, Africa in international politics, local government and administration, sociology and community development; vastly experienced public administrator; and an eminent scholar with specialist qualifications from University of South Africa, and from California University for Advanced Studies, State of California, United States of America: BA with majors in public administration and political science and subsidiaries in sociology, constitutional law and English; postgraduate special Hons BA [Public Administration]; MA [Public Administration]; MAdmin magna cum laude in transport economics as major, and minors in public management and communications; MSoc Sc cum laude in international politics as a major and minors in comparative government and law, war and strategic studies, sociology, and social science research methodologies; and PhD summa cum laude in Public Administration. 